\title{
IN-VIVO REPLICATION OF CYPRINID HERPESVIRUS-3 IN GOLDFISH
}

\author{
HATEM SOLIMAN \\ Department of Aquatic Animals Medicine and Management, Faculty of Veterinary Medicine, Assiut \\ University, Assiut, Egypt
}

Received: 30 June 2019; Accepted: 30 July 2019

\begin{abstract}
Cyprinid herpes virus-3 (CyHV-3) is the causative agent of the lethal, highly contagious and notifiable koi herpesvirus disease (KHVD) in common carp and koi. Since its first identification, outbreaks of KHVD have occurred worldwide with significant economic losses in common carp and ornamental koi aquaculture industries. In the present study, experimental infection of goldfish by immersion rout was established. Apparently healthy common carp and goldfish were exposed to various concentrations of the CyHV-3 and monitored for mortality and development of clinical signs. CyHV-3 DNA was detected in the tissues of the challenged goldfish and common carp, which confirm the suitability of the immersion route to be used for infection of goldfish with CyHV-3. In addition, CyHV-3 terminase gene was amplified from the RNA extracted from the goldfish gill tissues at two- and eight-days post exposure to CyHV-3. The primer set used for amplification of this gene is specific for RT-PCR and did not amplify this gene from DNA. Results of this investigation confirm the replication of CyHV-3 in the goldfish tissues, which act as a true carrier not a vector or fomites and establish the experimental infection of goldfish with $\mathrm{CyHV}-3$ by immersion route.
\end{abstract}

Keywords: CyHV-3, KHV, Koi, Carp, virus replication

\section{INTRODUCTION}

The common carp (Cyprinus carpio) is one of the oldest cultivated freshwater fish species (Balon, 1995) and is now one of the most economically valuable species in aquaculture. Its colorful ornamental varieties, koi carp, grown for personal pleasure and competitive exhibitions, represent one of the most expensive markets for individual freshwater fish (Ilouze et al., 2008). Goldfish (Carassius auratus) are also popular and cultured worldwide for aquaria and ponds for personal pleasure. In the late 1990s, a highly contagious and virulent disease began to cause severe economic losses to common and koi carp industries worldwide (Michel et al., 2010). The disease was reported in 1996 in England and 1997 in Germany (Bretzinger et al., 1999, Haenen et al., 2004). The etiological agent was initially identified from mass mortalities in the US and Israel as a herpes virus and given the name Koi herpes virus, KHV (Hedrick et al., 2000). Based on the homology of its genome with known cyprinid herpesviruses, the virus was subsequently assigned to the family Alloherpesviridae, genus Cyprinivirus, and renamed

Corresponding author: Dr. Hatem Soliman

E-mail address: hatemtoughan@hotmail.com

Present address: Department of Aquatic Animals Medicine and Management, Faculty of Veterinary Medicine, Assiut University, Assiut, Egypt
Cyprinid herpes virus 3, CyHV-3 (Waltzek et al., 2005). Many CyHV-3 outbreaks have been reported (reviewed in Gotesman et al., 2013). It is believed that the rapid spread of the virus was due to koi shows and the intense worldwide trade of koi carp, mostly without veterinary supervision. Intensive fish culture in the absence of health certifications or inspections has also probably contributed (Gilad et al., 2003 and Pikarsky et al., 2004). A complete infectious life cycle, regardless of virus classification, necessitates the attachment and entry of the virion particle into the host cell, viral translation of mRNA by host ribosomes, viral genome replication, assembly of viral particles and release of infectious particles from the cell (Lum and Cristea, 2016). The greatly reduced size of the viral genome means that it is not possible for viruses to encode all the proteins required for these processes. They have evolved mechanisms to hijack and subvert host-cell machinery to achieve their goals (Ramage and Cherry, 2015). The hosts have evolved sophisticated mechanisms to recognize and restrict the invading pathogens. Successful viruses manipulate hosts in a variety of ways, taking advantage of beneficial cellular pathways, while evading or inactivating factors that are detrimental to viral growth.

Mortality and morbidity associated with $\mathrm{CyHV}-3$ are restricted to koi and common carp (Michel et al., 2010, Gotesman et al., 2013). Other cyprinids, such as silver perch (Bidyanus bidyanus), silver carp 
(Hypophthalmichthys molitrix), goldfish (Carassius auratus) and grass carp (Ctenopharyngodon idella), have never shown any signs of CyHV-3 disease, even after long cohabitation with sick fish at a permissive temperature (Pikarsky et al., 2004 and Hedrick et al., 2006). However, CyHV-3 DNA was detected in tissues of commercial asymptomatic goldfish and grass carp that had cohabitated with CyHV-3-infected koi (El-Matbouli et al., 2007 and Sadler et al., 2008 and Bergmann et al., 2009). CyHV-3 was also propagated on cultured cells derived from common carp, koi, silver carp and goldfish, which is evidence that other cyprinids may become infected by CyHV-3 (Davidovich et al., 2007).

The aim of the present work was to investigate the susceptibility of goldfish to CyHV-3 infection via the immersion route and to prove the replication of CyHV-3 in the infecteds goldfish.

\section{MATERIALS AND METHODS}

\section{Propagation and titration of $\mathrm{CyHV}-3$}

Common carp brain (CCB) cells was cultured in minimum essential medium (MEM) with Earle's salts supplemented with $1 \%$ non-essential amino acids, $10 \%$ fetal bovine serum, $4.5 \mathrm{~g} /$ liter glucose, penicillin and streptomycin, and incubated at $22^{\circ} \mathrm{C}$ in a humidified atmosphere containing $5 \% \mathrm{CO} 2$. CCB cultures was inoculated with $\mathrm{CyHV}-3$, incubated at $22{ }^{\circ} \mathrm{C}$ in a humid atmosphere containing $5 \% \mathrm{CO} 2$, and examined for cytopathic effect (CPE). Subsequently, the medium harvested and the cellular debris removed by centrifugation for $10 \mathrm{~min}$ at 3000 $\mathrm{x} \mathrm{g}$. The virus was characterized by PCR as described by Bercovier et al. (2005) and sequenced. The infectivity of the virus $\left(\mathrm{TCID}_{50}\right)$ quantified according to Reed and Muench, (1938). The virus stock suspension was divided into aliquots and stored at $80{ }^{\circ} \mathrm{C}$ until used.

Determination the infective dose of the $\mathrm{CyHV}-3$

To mimic natural infection, fish was infected using immersion. After determining the CyHV-3 $\mathrm{TCID}_{50}$ on cell culture, different groups of apparently healthy common carp $(\mathrm{n}=15$, average length $=9-10 \mathrm{~cm})$ and goldfish $(\mathrm{n}=15$, average length $=8-9 \mathrm{~cm})$ exposed to different $\mathrm{CyHV}-3 \quad \mathrm{TCID}_{50}$ concentrations (100\% $\left.\mathrm{TCID}_{50} / \mathrm{ml}, 75 \% \mathrm{TCID}_{50} / \mathrm{ml} \& 50 \% \mathrm{TCID}_{50} / \mathrm{ml}\right)$ by immersion for $1 \mathrm{~h}$ (5 fish/ TCID $_{50}$ concentration / species), then transferred to a new tank and held at $25^{\circ} \mathrm{C}$. A control group for each concentration was exposed to a non-infected CCB cell suspension for $1 \mathrm{~h}$, transferred to a new tank and incubated at $25^{\circ} \mathrm{C}$. Fish were monitored for clinical signs of $\mathrm{CyHV}-3$ infection and mortality. Common carp that were moribund or exhibited clinical signs were sampled and tested for CyHV-3 DNA by PCR. Simultaneously, goldfish were sampled and tested for CyHV-3 DNA by PCR according to Bercovier et al., (2005).
Experimental infection of goldfish by $\mathrm{CyHV}-3$

Apparently healthy goldfish $(n=15$, average length $=$ 8-9 $\mathrm{cm}$ ) were obtained locally and kept for three weeks at $25{ }^{\circ} \mathrm{C}$ for acclimatization. Fish were randomly subjected to clinical, microbiological and parasitic examinations. DNA was extracted from the tissues and tested as described by Goodwine et al., (2006) and Gilad et al., (2004) to exclude CyHV-2 and CyHV-3 infections. Goldfish were divided into two groups ( $n=6$ each): the infection group was experimentally infected with the estimated CyHV-3 TCID $_{50}$ by immersion and the control group was mock-infected with the same volume of sterile CCB cell culture supernatant. The two groups of fish were maintained at $25^{\circ} \mathrm{C}$ for $1 \mathrm{~h}$. After viral exposure, they were transferred to separate 60 liter aquaria maintained at $25{ }^{\circ} \mathrm{C}$ and monitored daily. Three fish from each group were sampled at two days and eight days post exposure. After euthanization, gill tissues were sampled from each fish and preserved in RNAlater (Sigma) for RNA extraction.

\section{RNA extraction}

RNA was extracted from gill tissues using RNeasy Mini kit (QIAGEN). Gill tissues was grinded in liquid nitrogen using mortar and pestle and then $25 \mathrm{mg}$ tissue powder was transferred to a liquid nitrogencooled 2-ml tube. RNA extraction was then completed as per manufacturer's instructions. Any traces of DNA were removed by in-column digestion with DNase I, and the samples were tested for purity by PCR according to Bercovier et al., (2005).

\section{Reverse transcription - polymerase chain reaction (RT-PCR)}

A one-step RT-PCR was performed according to Yuasa et al., (2012) to amplify a 219 bp fragment of terminase gene with some modifications. Briefly, a reaction mix, $25 \mu \mathrm{l}$ end volume, was prepared containing 5x QIAGEN OneStep RT-PCR buffer, 15 pmol of each primer (KHVRT-F3: 5'GGCATCGACATCATGGTGCA-'3, KHVRT-R1: 5'-ATTGCCGCTGGAAGCCA-GGT-'3), RNase inhibitor, QIAGEN OneStep RT-PCR Enzyme Mix, $1 \mu \mathrm{g}$ RNA and RNase-free water. The reaction conditions were: reverse transcription (RT) step at 55 ${ }^{\circ} \mathrm{C}$ for $30 \mathrm{~min}$, with inactivation of RT at $94{ }^{\circ} \mathrm{C}$ for 2 min followed by 35 cycles of $30 \mathrm{~s}$ denaturation at 94 ${ }^{\circ} \mathrm{C}, 30 \mathrm{~s}$ annealing at $60{ }^{\circ} \mathrm{C}$ and $30 \mathrm{~s}$ elongation at 72 ${ }^{\circ} \mathrm{C}$ and a final elongation step at $72{ }^{\circ} \mathrm{C}$ for $10 \mathrm{~min}$. Negative extraction control and non-template controls were included. The amplified products were purified using MinElute gel extraction kit (QIAGEN) following the manufacturer's instructions and sequenced in a commercial sequencing laboratory (LGC Genomics, Berlin, Germany). The sequences were subjected to BLAST analysis for sequence similarity against GenBank database. 


\section{RESULTS}

CyHV-3 was propagated in CCB cells and the virus identity was confirmed by amplification the expected 409 bp fragment from the DNA extracted from CCB cell culture supernatant and sequence analysis, which revealed $99 \%$ identity with the CyHV-3 thymidine kinase (TK) gene.

The optimum CyHV-3 TCID $_{50}$ dose that caused morbidity and mortality in common carp, and had detectable DNA in the corresponding goldfish group, was $75 \% \mathrm{TCID}_{50}\left(10^{3} \mathrm{TCID}_{50} / \mathrm{ml}\right)$ and this dose was selected as the infective dose for the subsequent experiment. The expected $409 \mathrm{bp}$ amplicon did not amplify from RNA extracted from the goldfish sampled at the two different time points, which confirm the absence of any DNA traces in the RNA samples.

The expected 219 bp amplicon of CyHV-3 terminase gene was amplified from the goldfish RNA samples, by utilizing RT-PCR, at the both time points; twoand eight-days post infection while no amplification products were detected in the negative extraction or non-template controls (Figure 1). Sequence analysis of the amplified products by BLASTn revealed a $99 \%$ homology with the CyHV-3 terminase gene sequences (GenBank accession numbers KX544848, KJ627438, AP008984, DQ657948, \& DQ177346).

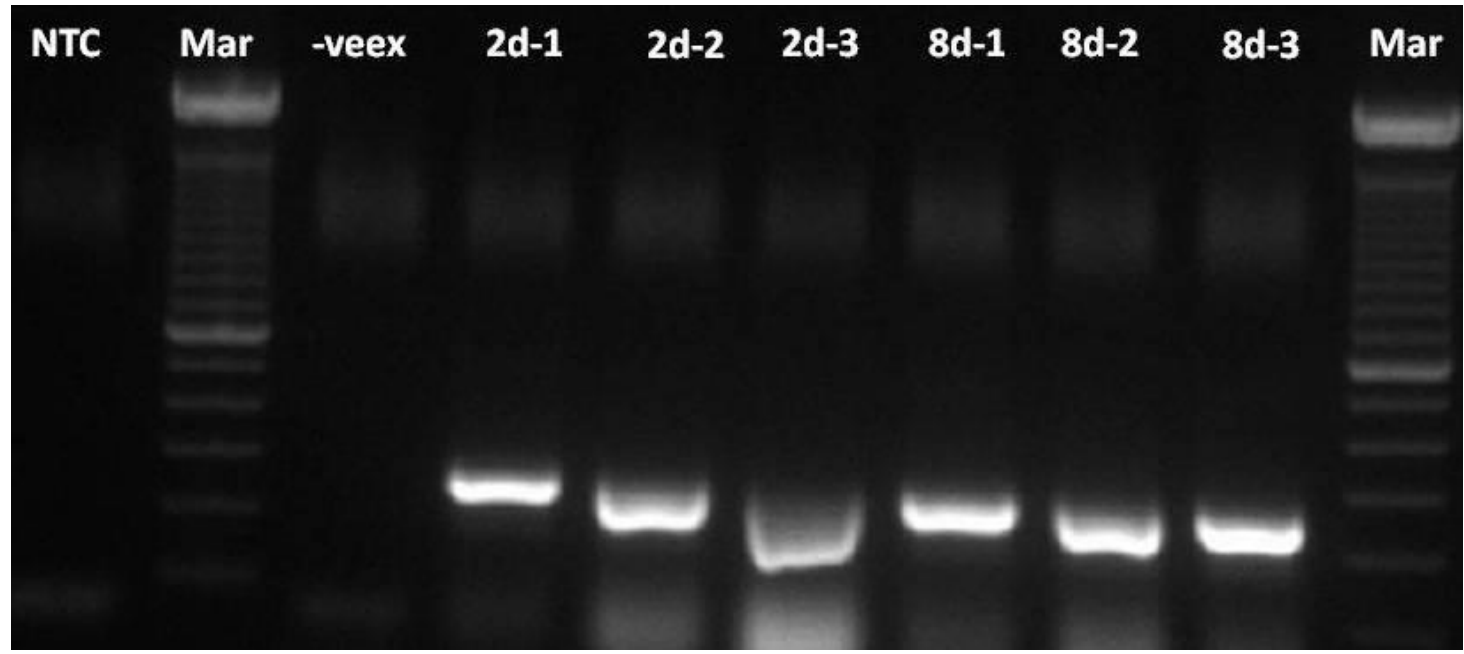

Figure 1:

Reverse transcription-PCR amplification of the 219 bp fragment of CyHV-3 putative terminase gene from RNA samples extracted from goldfish gill tissues 2 days and 8 days post-infection. NTC $=$ Non-template control, Mar= 100 bp DNA Marker, $-\mathbf{v e e x}=$ Negative extraction control, 2d-= Two-days post infection, 8d = Eight-days post infection.

\section{DISCUSSION}

Cyprinid herpesvirus-3 (CyHV-3) is a notifiable, lethal virus that threatens koi and common carp populations worldwide. Although experimental infection of common carp with CyHV-3 by immersion has been demonstrated (Bergmann et al., 2009), experimental infection of goldfish with CyHV-3 by immersion rout have not performed or optimized yet. Previous works has demonstrated that CyHV-3 can infect goldfish, then egress to infect naïve carp, without causing clinical disease or mortality in the goldfish (El-Matbouli et al., 2007 and El-Matbouli and Soliman, 2011). However, there is no evidence that goldfish can act as a vector or fomites that can be contaminated with the CyHV-3 and transfer it to other susceptible hosts or as a true carrier in which CyHV-3 can replicates and disseminate to other susceptible hosts. The present work was carried out to investigate the ability of CyHV-3 to replicate in goldfish.
Results of this work proved that goldfish can be infected with CyHV-3 by immersion route which mimic the natural infection. The optimum dose of CyHV-3 for immersion infection was estimated to be $10^{3} \mathrm{TCID}_{50} / \mathrm{ml}$ in this study, however, the virus infectivity varies by several factors such as: virus strain, number of subculture and water temperature (Michel et al., 2010).

Previous studies demonstrate that the portal of entry and replication of $\mathrm{CyHV}-3$ are gills and skin (Pikarsky et al., 2004). During the development of the infection, the virus load increases rapidly in gills and skin of infected carp and causes branchial and epidermal hyperplasia resulting in branchial necrosis and skin lesions (Hedrick et al., 2000 and Pikarsky et al., 2004). Several CyHV-3 genes are expressed abundantly in gills during the acute and reactivation phases (Sunarto et al., 2014). Accordingly, the gill tissues were selected in this study to be sampled to prove the replication of the CyHV-3 in goldfish. 
In vitro studies show that transcription of CyHV-3 genes starts as early as $1 \mathrm{~h}$ post-infection and viral DNA synthesis initiates 4-8h post-infection (Ilouze et al., 2012). Moreover, CyHV-3-specific RNA can be detected in tissues as early as $12 \mathrm{~h}$ post-exposure, and CyHV-3 DNA can be recovered from almost all internal tissues as early as $24 \mathrm{~h}$ post-infection (Gilad et al., 2004 and Miyazaki et al., 2008). Based on the literature, the first clinical signs of $\mathrm{CyHV}-3$ infection appear in common carp 2-3d post-exposure and the highest mortality rates occur in common carp 8-12d post-infection (Gilad et al., 2004 and Miyazaki et al., 2008, Costes et al., 2009 and Michal et al., 2010). Accordingly, the two time points that selected to investigate the replication of the $\mathrm{CyHV}-3$ in the goldfish was selected at two and eight days which are parallel to the days at which the clinical signs and highest mortality in common carp appears respectively. Presence and replication of the CyHV-3 in the goldfish tissues during this period without producing any clinical signs or mortality confirm that the goldfish is a true carrier for CyHV-3 not only a vector or fomites.

To infer if the virus is replicating, it is recommended to assay the viral mRNA (Yuasa et al., 2012). To avoid amplification of genomic DNA; RT-PCR utilizing splice-junction-spanning primers is used to amplify target gene from RNA samples without amplifying any genomic DNA (Sternberg et al., 2004). The primers used in this study was designed in spliced variants of terminase gene to establish specific RT-PCR assay for detection the replication of CyHV-3 (Yuasa et al., 2012). Detection of the putative $\mathrm{CyHV}-3$ terminase gene in RNA samples that extracted from goldfish gill tissues two- and eight- days post infection, confirm the replication of CyHV-3 in the goldfish tissues and prove the infection of goldfish by the immersion method.

\section{CONCLUSIONS}

The putative CyHV-3 terminase gene was transcribed in goldfish gill tissues two- days and eight -days post infection, confirming the replication of $\mathrm{CyHV}-3$ in the goldfish tissues and proving the infection of goldfish by the immersion method.

\section{REFERENCES}

Balon, E.K. (1995): Origin and domestication of the wild carp, Cyprinus Carpio: From Roman gourmets to the swimming flowers. Aquaculture 129: 3-48.

Bercovier, H.; Fishman, Y.; Nahary, R.; Sinai, S.; Zlotkin, A.; Eyngor, M.; Gilad, O.; Eldar, A. and Hedrick, R.P. (2005): Cloning of the koi herpesvirus (KHV) gene encoding thymidine kinase and its use for a highly sensitive PCR based diagnosis. BMC Microbiol 5: 13.
Bergmann, S.M.; Schütze, H.; Fischer, U.; Fichtner, D.; Riechardt, M.; Meyer, K.; Schrudde, D. and Kempter, J. (2009): Detection of koi herpes virus (KHV) genome in apparently healthy fish. Bull Eur Ass Fish Pathol 29: 145152.

Bretzinger, A.; Fischer-Scherl, T.; Oumouna, M.; Hoffmann, R. and Truyen, U. (1999): Mass mortality in koi carp, Cyprinus carpio, associated with gill and skin disease. Bull Eur Assoc Fish Pathol 19:182-185.

Costes, B.; Raj, V. S.; Michel, B.; Fournier, G.; Thirion, M.; Gillet, L.; Mast, J.; Lieffrig, F.; Bremont, M. and Vanderplasschen, A. (2009): The major portal of entry of koi herpesvirus in Cyprinus carpio is the skin. $\mathrm{J}$ Virol 83:2819-2830.

Davidovich, M.; Dishon, A.; Ilouze, M. and Kotler, M. (2007): Susceptibility of cyprinid cultured cells to cyprinid herpesvirus -3. Arch Virol 152: 1541- 1546

El-Matbouli, M.; Saleh, M. and Soliman, H. (2007): Detection of Cyprinid herpesvirus type 3 in goldfish cohabitating with CyHV-3-infected koi carp (Cyprinius carpio koi). Vet Rec 161: 792-793.

El-Matbouli, M. and Soliman, H. (2011): Transmission of Cyprinid herpesvirus-3 (CyHV-3) from goldfish to naïve common carp by cohabitation. Res Vet Sci 90: 536-539.

Gilad, O.; Yun, S.; Andree, K.B.; Adkison, M. A.; Way, K.; Willits, N.H.; Bercovier, H. and Hedrick, R.P. (2003): Molecular comparison of isolates of an emerging fish pathogen, the koi herpesvirus, and the effect of water temperature on mortality of experimentally infected koi. J Gen Virol 84: 1-8.

Gilad, O.; Yun, S.; Zagmutt-Vergara, F.J.; Leutenegger, C. M.; Bercovier, H. and Hedrick, R.P. (2004): Concentrations of a koi herpesvirus (KHV) in tissues of experimentally infected Cyprinus carpio koi as assessed by real-time TaqMan PCR. Dis Aquat Organ 60: 179-87.

Goodwin, A.E.; Khoo, L.; Lapatra, S.E.; Bonar, C.; Key, D.W. and Garner, M. (2006): Goldfish Hematopoietic Necrosis Herpesvirus (Cyprinid Herpesvirus 2) in the USA: Molecular Confirmation of Isolates from Diseased Fish. J Aquat Anim Health 18: 11-18.

Gotesman, M.; Kattlun, J.; Bergmann, S.M. and ElMatbouli, M. (2013): CyHV-3: the third cyprinid herpesvirus. Dis Aquat Organ 105: 163-174.

Haenen, O.L.M.; Way, K.; Bergmann, S.M. and Ariel, $E$. (2004): The emergence of koi herpesvirus and its significance to European aquaculture. Bull Eur Assoc Fish Pathol 24: 293-307.

Hedrick, R.P.; Gilad, O.; Yun, S.; Spangenberg, J.V.; Marty, G.D.; Nordhausen, R.W.; Kebus, M.J.; Bercovier, H. and Edlar, A. (2000): A 
herpesvirus associated with mass mortality of.juvenile and adult koi, a strain of a common carp. J Aquat Anim Health 12: 44-57.

Hedrick, R.P.; Waltzek, T.B. and McDowell, T.S. (2006): Susceptibility of koi Carp, common carp Goldfish and goldfish $\mathrm{X}$ common carp hybrids to cyprinid herpesvirus-2 and herpesvirus-3. J Aquat Anim Health 18: 26-34.

Ilouze, M.; Dishon, A.; Davidovich, M.; Perelberg, A. and Kotler, M. (2008): KHV, CNGV or CyHV-3, which is the koi/carp killer? pp. 115128. In Bondad-Reantaso, M.G., Mohan, C.V., Crumlish, M. and Subasinghe, R.P. (eds.). Diseases in Asian Aquaculture VI. Fish Health Section, Asian Fisheries Society. Manila, Philippines.

Ilouze, M.; Dishon, A. and Kotler, M. (2012): Coordinated and sequential transcription of the cyprinid herpesvirus-3 annotated genes. Virus Res 169: 98-106.

Lum, K. K. and Cristea, I. M. (2016): Proteomic approaches to uncovering virus-host protein interactions during the progression of viral infection. Expert Rev Proteomics 13: 325-340.

Michel, B.; Fournier, G.; Lieffrig, F.; Costes, B. and Vanderplasschen, A. (2010): Cyprinid Herpesvirus 3. Emerg Infect Dis 16: 18351843.

Pikarsky, E.; Ronen, A.; Abramowitz, J.; LevaviSivan, B.; Hutoran, M.; Shapira, Y.; Steinitz, M.; Perelberg, A.; Soffer, D. and Kotler, M. (2004): Pathogenesis of acute viral disease induced in fish by carp interstitial nephritis and gill necrosis virus. J Virol 78: 9544-9551.

Ramage, H. and Cherry, S. (2015): Virus-Host Interactions-from unbiased genetic screens to function. Annu Rev Virol 2: 19.1-19.28.

Reed, L. J. and Muench, H. (1938): A simple method of estimating fifty percent endpoints. Am J Epidemiol 27: 493e7.

Sadler, J.; Marecaux, E. and Goodwin, A.E. (2008): Detection of koi herpes virus (CyHV-3) in goldfish, Carassius auratus (L.), exposed to infected koi. J Fish Dis 31: 71-72.

Sternber, g L.R.; Byrd, J.C.; Hansson, G. C.; Liu, K. F. and Bresalier, R. S. (2004): Alternative splicing of the human MUC2 gene. Arch Biochem Biophys 421: 21-33.

Sunarto, A.; McColl, K. A.; Crane, M. St J.; Schat, K. A.; Slobedman, B.; Barnes, A. C. and Walker, P.J. (2014): Characteristics of cyprinid herpesvirus 3 in different phases of infection: Implications for disease transmission and control. Virus Res 188: 45-53.

Waltzek, T.B.; Kelley, G.O.; Stone, D.M.; Way, K.; Hanson, L.; Fukuda, H.; Hirono, I.; Aoki, T.; Davison, A. J. and Hedrick, R. P. (2005): Koi herpesvirus represents a third cyprinid herpesvirus (CyHV-3) in the family Herpesviridae. J Gen Virol 86: 1659-67.

Yuasa, K.; Kurita, J.; Kawana, M.; Kiryu, I.; Oseko, N. and Sano, M. (2012): Development of mRNA-specific RT-PCR for the detection of koi herpesvirus (KHV) replication stage. Dis Aquat Org 100: 11-18.

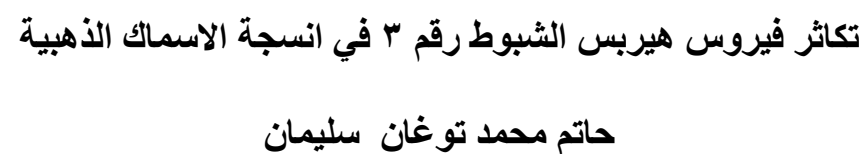

E-mail: hatemtoughan@hotmail.com

Assiut University web-site: www.aun.edu.eg

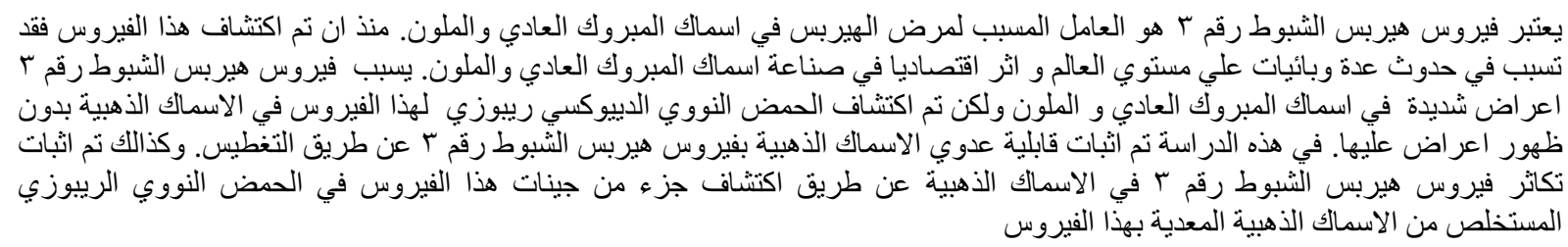

